PUSTABIBLIA: Journal of Library and Information Science

ISSN 2549-3493 (Print); ISSN 2549-3868 (Online)

DOI: http://dx.doi.org/10.18326/pustabiblia.v5i2.323-346

SK Dirjen Risbang-Kemristekdikti No 23/E/KPT/2019 (Peringkat 4 SINTA)

\title{
Penggunaan Konsep User Experience Terhadap Layanan Situs Web Perpustakaan
}

\author{
Laylatul Munawaroh \\ Program Pascasarjana UIN Sunan Kalijaga Yogyakarta \\ Email: laylatulmunawaroh1@gmail.com
}

Naskah diterima: 04-10-2021, direvisi: 05-11-2021, disetujui: 07-11-2021

\begin{abstract}
Building a website should be designed based on the experience of the user, as the user who uses the web service. The basics of user experience are needed in designing a library website. The better the user experience in using a library website, the better the quality of a library's web service will be. Building a library web system requires knowledge of User Experience (UX), so that user satisfaction and convenience can be met. Weboriented user experience can provide an impressive experience for users with features and content that is not confusing and easy to understand. With the steps in arranging UX into elements, we can better understand the overall task of building a website. According to Jesse James Garett, these elements are divided into five, namely: the strategy plane, the scope plane, the structure plane, the skeleton plane, and the surface plane.
\end{abstract}

Keywords: web-based library, user experience, five elements.

\section{Abstrak}

Membangun sebuah situs web harus dirancang berdasarkan pengalaman pemustaka, sebagai pengguna yang menggunakan layanan web tersebut. Dasar-dasar user experience sangat dibutuhkan dalam merancang sebuah situs web perpustakaan. Semakin baik pengalaman pemustaka dalam menggunakan situs web perpustakaan, maka akan semakin baik pula kualitas layanan web suatu perpustakaan. Dalam 
membangun sistem web perpustakaan membutuhkan pengetahuan tentang User Experience (UX), sehingga kepuasan dan kenyamanan pemustaka dapat terpenuhi. Web yang berorientasikan pada pengalaman pemustaka dapat memberikan pengalaman yang mengesankan bagi pemustaka dengan fitur dan konten yang tidak membingungkan serta mudah dimengerti. Dengan adanya langkah dalam menyusun UX menjadi elemen-elemen, kita dapat lebih memahami tugas secara keseluruhan dalam membangun sebuah situs web. Menurut Jesse James Garett, elemen-elemen tersebut terbagi menjadi lima, yaitu: bidang strategi (strategy plane), bidang lingkup (scope plane), bidang struktur (structure plane), bidang rangka (skeleton plane), dan bidang permukaan (surface plane).

Kata kunci: perpustakaan berbasis web, user experience, lima elemen.

\section{A. PENDAHULUAN}

Perpustakaan merupakan institusi yang menjadi wadah dalam kegiatan mengumpulkan, mengelola, melestarikan, dan menyajikan informasi kepada masyarakat pengguna. Orientasi utama perpustakaan ialah layanan yang berlandaskan pada kebutuhan pemustaka (pengguna) yang berusaha untuk mempertemukan sumber informasi dengan pemustaka secara luas. Sampai saat ini, perpustakaan telah beradaptasi, menambahkan, dan berkembang dari segi pengelolaan dan layanan perpustakaan. Perpustakaan tidak hanya melakukan kegiatan peminjaman dan pengembalian buku, namun telah memperluas jangkauan kegiatan salah satunya dengan mengakses informasi dalam bentuk cetak dan non-cetak.

Dewasa ini, perkembangan perpustakaan semakin melaju seiring dengan revolusi teknologi informasi yang menuntut perpustakaan melakukan perubahan dari perpustakaan tradisional menjadi perpustakaan modern (Abbas and Faiz 2013, 151). Kondisi inilah yang mengharuskan berubahnya pola pikir dalam pengelolaan perpustakaan. Perubahan pola pikir tersebut dilihat dari aspek sumber daya koleksi perpustakaan yang dahulu hanya terdiri dari satu media yaitu bentuk tercetak dan berubah menjadi koleksi digital. Kemudian dari aspek jasa layanan perpustakaan yang semula berada pada ruangan, sekarang berkembang layanan perpustakaan modern yang berbasis 
virtual. Perubahan tersebut didukung dengan perkembangan teknologi informasi, sehingga munculah berbagai layanan-layanan perpustakaan secara virtual seperti perpustakaan berbasis web yang dapat menjangkau pemustaka dengan cakupan yang lebih luas tanpa dibatasi oleh ruang dan waktu.

Terbentuknya perpustakaan berbasis web sebagai implementasi dari sistem informasi pada perpustakaan yang lebih memudahkan aktivitas penelusuran informasi bagi pemustaka dan kemudahan dalam aksesibilitas layanan perpustakaan. Perpustakaan berbasis web dapat menghubungkan perpustakaan pada pemustaka dalam jarak jauh. Pada situs web perpustakaan memuat banyak konten layanan yang dapat diakses oleh pemustaka seperti informasi tentang layanan, katalog online, bahan perpustakaan digital, e-learning, tanya pustakawan, dsb. namun adakalanya beberapa konten yang telah disediakan terkubur dalam situs itu sendiri karena sulit ditemukan oleh pemustaka karena desain web yang sulit dimengerti oleh pemustaka. Sudah selayaknya web perpustakaan di desain berdasarkan pada kebutuhan pemustaka, karena selain dari aspek informasi yang disajikan, baik buruknya perpustakaan dapat dilihat dari aspek layanan yang diberikan kepada pemustaka. Dalam membangun sistem web perpustakaan membutuhkan pengetahuan tentang pengalaman pengguna atau User Experience (UX), sehingga kepuasan dan kenyamanan pemustaka dapat terpenuhi. Web yang berorientasikan pada pengalaman pemustaka dapat memberikan pengalaman yang mengesankan bagi pemustaka dengan fitur dan konten yang tidak membingungkan serta mudah dimengerti.

Pengalaman pengguna (UX) adalah bagaimana perasaan orang ketika mereka menggunakan produk atau layanan. Ini adalah situasi ideal di mana pengguna mendapatkan kepuasan maksimal dari menggunakan produk atau layanan. Pengalaman pengguna dapat mencakup semua jenis produk, dalam kebanyakan kasus, produk tersebut dapat berbentuk situs web atau aplikasi. Setiap interaksi manusia dengan objek memiliki pengalaman pengguna, tetapi praktisi UX lebih cenderung kepada hubungan antara pengguna manusia dengan komputer dan produk berbasis komputer, seperti situs web, aplikasi, dan sistem (Deacon 2020, 7). Untuk membangun suatu 
web yang berorientasi pada pengguna, menempuh tahap atau elemen yang perlu dipertimbangkan. Menurut Jesse James Garett, elemen-elemen tersebut terbagi menjadi lima, yaitu: bidang strategi (strategy plane), bidang lingkup (scope plane), bidang struktur (structure plane), bidang rangka (skeleton plane), dan bidang permukaan (surface plane) (Garett 2011). Pada tulisan ini, menjelaskan bagaimana konsep User Experience (UX) dalam membangun desain web perpustakaan melalui lima elemen yang diutarakan Jesse James Garett yang dikenal sebagai seorang konsultan user experience, sehingga dapat diterapkan pada perpustakaan agar mampu memberikan kepuasan pada pemustaka yang berselancar informasi di web perpustakaan.

\section{B. TINJAUAN PUSTAKA}

\section{Perpustakaan Berbasis Web}

Dalam mempermudah tugas pustakawan dalam mengelola perpustakaan, pustakawan membutuhkan sistem informasi sebagai penunjang dalam kegiatan di perpustakaan. Semua di proses secara komputerisasi yaitu menggunakan suatu software tertentu sebagai pengolah database. Sistem informasi perpustakaan merupakan kumpulan informasi yang saling terintegrasi satu sama lain. Tujuan dari menggunakan sistem informasi adalah untuk memudahkan aksesibilitas pemustaka dalam mengakses layanan-layanan dan informasi yang disediakan di perpustakaan. Menururt Remick, aplikasi web merupakan sebuah aplikasi yang dapat dijalankan dengan menggunakan teknologi browser dan diakses melalui jaringan internet. Sedangkan menurut Rouse, aplikasi web adalah sebuah program yang disimpan di Server dan dan dikirim melalui internet dan diakses melalui antarmuka browser (Fahmi et al. 2016).

Menurut Hartono, penerbitan atau pembuatan situs web bertujuan untuk mempublikasikan berbagai informasi tentang perpustakaan dan segala kegiatannya. Kegiatan tersebut, pada dasarnya sama dengan layaknya publikasi dalam bentuk konvensional seperti seberan, brosur, pamflet panduan perpustakaan, katalog dalam berbagai jenis, serta kegiatan publikasi 
lainnya (Hartono 2017).

Setiap halaman web layanan perpustakaan dibagi menjadi beberapa bagian untuk membantu pengguna menemukan jenis informasi secara cepat. Setiap bagian mewakili modul informasi dengan tujuan spesifik dan mengidentifikasi desain; bagian diberi kode warna dan ditampilkan dalam urutan yang konsisten pada setiap halaman. Ini membantu pengguna untuk menemukan jenis informasi yang sama di tempat yang sama di setiap halaman layanan web. Bagian utama meliputi: judul-judul koleksi, deskripsi, kata kunci, jam, lokasi, kontak, gambaran, panggilan untuk bertindak, pertanyaan yang sering diajukan, sumber daya tambahan, layanan terkait, dan kategori (Rennick 2019).

\section{Definisi User Experience (UX)}

Kata "pengguna (user)" adalah bentuk nominal dari "menggunakan (to use)", kata tersebut berasal dari kata kerja latin "oeti," yang berarti menerapkan atau menggunakan sesuatu. Sebaliknya, kata "pengalaman (experience)" berasal dari kata latin "experienta", yang berarti pengetahuan yang diperoleh dari praktik dan percobaan terus menerus. Pengalaman pengguna (UX) adalah pengetahuan yang diperoleh dari melakukan sesuatu atau kepuasan yang diperoleh dari penggunaan suatu produk atau layanan (Deacon 2020,7).

Menurut definisi dari ISO 9241-210, user experience adalah persepsi seseorang dan responnya dari penggunaan sebuah produk, sistem, atau jasa. Selanjutnya, emosi, keyakinan, persepsi, respon fisik maupun psikologi, perilaku dan prestasi yang terjadi sebelum, selama, dan setelah digunakan merupakan bagian dalam kajian UX (Interaction 2010). Sedangkan menurut Winter dalam Munthe et al. (2018) user experience adalah bagaimana perasaan pengguna terhadap setiap interaksi yang sedang pengguna hadapi dengan apa yang ada di depan pengguna saat menggunakannya. Membangun sebuah situs web haruslah berorientasi pada user karena yang akan mengakses dan menikmati web tersebut adalah user itu sendiri, semakin baik pengalaman user dalam menggunakan suatu situs web, maka dapat dikatakan semakin 
baik pula kualitas situs web tersebut.

Menurut Garett, merupakan sesuatu yang aneh jika seseorang merasa kesulitan dalam menggunakan situs web. Pengguna akan merasa telah melakukan hal yang salah dan merasa menyalahkan diri sendiri atas ketidaktahuan mereka dalam mengakses suatu situs web. Namun, hal tersebut bukanlah kesalahan dari pengguna jika suatu situs web tidak berfungsi sebagaimana yang mereka harapkan (Garett 2011, 10). Dapat dikatakan bahwa jika pengguna memiliki pengalaman yang buruk, mereka tidak akan kembali mengunjungi situs web tersebut. Jika mereka memiliki pengalaman yang baik dengan situs web, maka pengguna senantiasa mengunjungi situs web ketika diperlukan. Fitur dan konten dalam web memang penting, tetapi pengalaman pengguna (user experience) memiliki efek yang jauh lebih besar pada loyalitas pengguna.

Kegagalan dalam mendesain situs web dapat dihindari jika creator menentukan pilihan yang tepat dalam mendesain produk webnya. Kegagalan dalam desain sebuah situs web menunjukkan kurangnya perhatian akan pengalaman pengguna. Ketika suatu web sedang dibangun dan dikembangkan, para creator menaruh perhatian besar pada apa yang sedang mereka bangun. Sedangkan pengalaman pengguna menjadi sisi yang seringkali diabaikan. Kemudian keberhasilan sebuah situs web adalah yang dibangun berdasarkan sisi kebutuhan dan kenyaman pengguna dalam mengakses situs web tersebut.

\section{User Experience Menurut Jasse James Garett}

Jesse James Garrett adalah salah satu pendiri Adaptive Path, sebuah konsultasi user experience yang berbasis di San Francisco. Sejak 1995, Garett telah mengerjakan proyek Web untuk perusahaan seperti AT\&T, Intel, Boeing, Motorola, Hewlett-Packard, dan National Public Radio. Kontribusinya pada bidang pengalaman pengguna termasuk Visual Vocabulary, sistem notasi terbuka untuk dokumentasi arsitektur informasi yang sekarang digunakan oleh organisasi di seluruh dunia. Situs pribadinya di www.jjg.net adalah salah satu tujuan Web paling populer untuk sumber daya arsitektur informasi, dan 
ia sering menjadi pembicara pada arsitektur informasi dan masalah user experience (Garett 2011). Pada tahun 2011, Garett mempublikasikan bukunya yang berjudul The Elements of User Experience User: Centered Design for the Web and Beyond Second Edition sebagai kelanjutan dari buku edisi pertama.

Proses desain UX adalah tentang memastikan bahwa tidak ada aspek pengalaman pengguna dengan kesengajaan terjadi tanpa maksud yang jelas. Memperhitungkan setiap kemungkinan dari setiap tindakan yang mungkin dilakukan oleh pengguna dan memahami harapan pengguna di setiap langkah selama proses tersebut. Dengan adanya langkah dalam menyusun UX menjadi elemen-elemen, kita dapat lebih memahami tugas secara keseluruhan dalam membangun sebuah situs web. Elemen-element tersebut terbagi menjadi lima, yaitu: bidang strategi (strategy plane), bidang lingkup (scope plane), bidang struktur (structure plane), bidang rangka (skeleton plane), dan bidang permukaan (surface plane) (Garett 2011, 20).

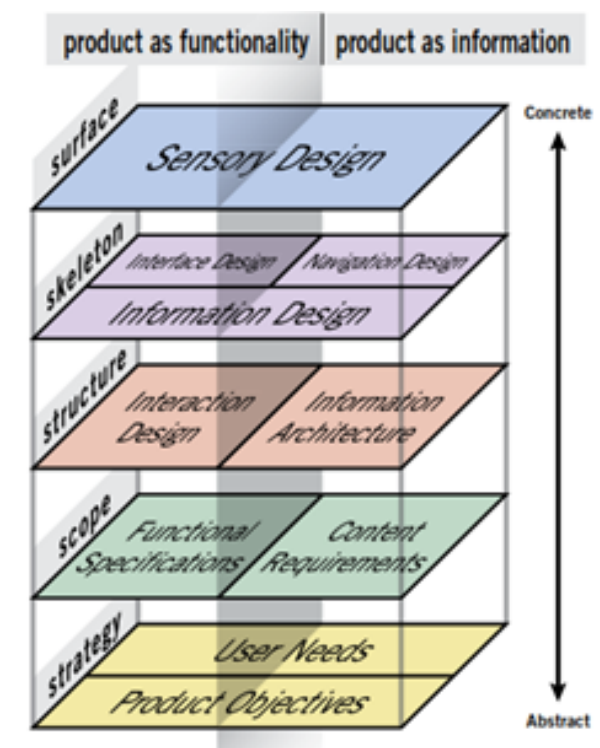

Gambar 1. Elemen user experience

Sumber: Garett, J. J. The Elements of User Experience: User-Centered Design for the Web and Beyond Second Edition (2011) 


\section{a. Bidang Strategi (Strategy Plane)}

Bidang strategi merupakan tahap menggambarkan tujuan produk yang berasal dari dalam organisasi dan membahas tentang apa yang dibutuhkan oleh pengguna sehingga membentuk suatu strategi yang menjadi pondasi untuk setiap pengambilan keputusan. Pada bidang strategi terbagi menjadi dua yaitu objek dari produk dan kebutuhan pengguna (Garett 2011, 36). Pada objek produk dimulai dengan rumusan semua objek yang ingin dicapai sehingga dalam membangun situs web, para creator mengerti apa yang sedang dan akan yang dibangun dalam web tersebut. Objek dalam hal ini berupa tujuan yang akan dicapai oleh internal organisasi berupa deskripsi strategi, kemudian identitas branding, dan metrik pencapaian yang ingin diwujudkan untuk mengetahui apakah target pencapaian telah didapatkan atau belum.

Kemudian dari segi kebutuhan pengguna perlu dilakukan beberapa pendekatan dan penelitian mengenai perilaku pengguna. Dimulai membuat suatu segmentasi pengguna dengan membagi pengguna menjadi beberapa kelompok dengan kriteria-kriteria tertentu seperti jenis kelamin, umur, tingkat pendidikan, profesi, penghasilan, serta sikap dan persepsi pengguna. Kemudian dengan mengidentifikasi kegunaan dan penelitian tentang pengguna dengan cara survey, wawancara, atau diskusi kelompok terarah. Selanjutnya mengumpulkan data-data tentang pengguna atau profil pengguna untuk memastikan bahwa selama mendesain web, kita akan mengingat kebutuhan pengguna. Bidang strategi adalah merupakan pondasi utama dalam UX, oleh karena nya perencanaan dalam mempertimbangkan aspekaspek tersebut perlu dilakukan guna membangun pondasi yang kuat.

\section{b. Bidang Lingkup (Scope Plane)}

Tahap bidang lingkup mengenai apa yang menjadi batasan dalam penciptaan pengalaman bagi pengguna. Di bidang ini Garett membagi menjadi dua sisi yaitu: sisi software interface (konten) dan hypertext system (konteks). Di sisi konteks, sistematika fungsional harus dipertimbangkan. Sedangkan di sisi konten, kebutuhan-kebutuhan informasi harus pula 
dipertimbangkan secara matang. Batasan Lingkup juga harus datang dari berbagai departmen dalam organisasi Sebagai contoh: Sebuah perusahaan ingin menjual beberapa produk memerlukan beberapa informasi seperti: deskripsi produk, alasan pembelian produk, benefit produk, shopping cart untuk pembelian e-commerce, metode pembayaran, dan sebagainya. Dalam setiap lingkup diperlukan kebutuhan (requirement) tertentu, misalnya: pada lingkup kategori produk, diperlukan spesifikasi produk, foto produk, warna produk, dan sebagainya (Munthe, Brata, and Fanani 2018, 1161). Fitur dan konten penting untuk di prioritaskan dalam memuaskan kebutuhan pengguna.

\section{c. Bidang Struktur (Structure Plane)}

Tahap bidang struktur (struktur plane) adalah tahap pembuatan struktur informasi agar komunikasi berjalan sesuai dengan urutan yang diharapkan. Pada tahap ini terbagi menjadi dua struktur yang harus dibentuk, yaitu desain interaksi dan arsitektur informasi. Desain interaksi berkaitan dengan menggambarkan kemungkinan perilaku pengguna dan menentukan bagaimana sistem akan mengakomodasi dan merespon perilaku pengguna tersebut (Garett 2011, 81). Desain interaksi dapat menggambarkan struktur informasi secara konseptual tentang bagaimana alur kerja pengguna dalam mengakses situs web sehingga kesalahan dalam memanfaatkan konten pada web dapat diperkecil atau diminimalisir.

Kemudian arsitektur informasi adalah tentang bagaimana menyusun informasi sehingga dapat dimengerti dan digunakan, karena arsitektur informasi berkaitan dengan bagaimana pengguna memproses informasi tersebut secara kognitif sehingga informasi yang disajikan dapat dipahami oleh pengguna (Garett, 2011, 88). Arsitektur informasi dapat berupa susunan konten, fitur, bahasa, dan metadata yang dimuat dalam situs web. Dalam pembentukan struktur informasi harus berdasarkan pada kemudahan pengguna dalam mengakses informasi. Untuk menggambarkan struktur informasi dapat disajikan dalam bentuk flowchart. Desain interaksi dan arsitektur informasi berbagi penekanan pada hal menentukan pola dan 
urutan di mana opsi akan disajikan kepada pengguna. Desain interaksi menyangkut pilihan yang terlibat dalam melakukan dan menyelesaikan tugas. Arsitektur informasi berkaitan dengan opsi-opsi yang terlibat dalam penyampaian informasi kepada pengguna.

\section{d. Bidang Rangka (Skeleton Plane)}

Bidang rangka merupakan tahap yang dibentuk pada model UX setelah bidang struktur telah diterapkan. Secara fungsionalitas, bidang kerangka meliputi interface design, navigation design, dan information design. Interface design atau desain antarmuka adalah semua tentang memilih elemen antarmuka yang tepat untuk halaman web sehingga pengguna dapat menyelesaikan dan mengaturnya di layar dengan cara yang mudah dipahami. Salah satunya tantangan terbesar dalam merancang desain antarmuka yang kompleks adalah mencari tahu aspek mana yang tidak perlu diakses pengguna. Adapun beberapa elemen standar desain antarmuka yaitu, kotak centang, tombol opsi, bidang masukan teks, daftar dropdown, list boxes, dan action buttons (Garett 2011, 114).

Navigation design atau desain navigasi dibuat bertujuan agar pengguna mendapatkan informasi dengan mudah dan cepat. Terdapat tiga tujuan simultan yang harus disediakan, yaitu: pertama, harus memberi pengguna sarana untuk berpindah dari satu titik ke titik lainnya di situs karena setiap tautan harus memiliki kinerja dan fungsi. Kedua, desain navigasi harus mengkomunikasikan ikatan antara elemen-elemen yang dikandungnya hal tersebut diperlukan bagi pengguna untuk memahami pilihan apa tersedia untuk mereka. Ketiga, desain navigasi harus mengkomunikasikan hubungan antara kontennya dan halaman yang sedang dilihat pengguna. Mengkomunikasikan hal ini membantu pengguna memahami pilihan mana yang tersedia yang paling tepat dalam mendukung tugas atau tujuan yang mereka inginkan (Garett 2011, 118).

Information design atau desain informasi merupakan pengelompokkan dan pengaturan elemen-elemen informasi dengan cara yang mencerminkan cara penggunanya yang mendukung tugas dan tujuan pengguna. Desain 
informasi mungkin sedikit sulit dilakukan. Tetapi desain informasi berfungsi sebagai lem yang melekatkan bersama dengan desain komponen lain. kuncinya adalah mengelompokkan dan mengatur elemen-elemen informasi dengan cara mencerminkan cara pengguna dalam berpikir dan mendukung tugas dan tujuan pengguna. Pada tahap ini biasanya disebut dengan wireframes yaitu tata letak halaman, dimana sebagai tempat dari desain informasi, desain antarmuka, dan desain navigasi yang membentuk suatu kesatuan kohesif (Garett 2011, 127). Pada bagian rangka ini, semua perencanaan elemen yang telah tersusun dari mulai strategi, ruang lingkup, dan struktur informasi diimplementasikan dalam bentuk nyata (tampilan web).

\section{e. Bidang Permukaan (Surface Plane)}

Pada tahap ini merupakan tahap akhir dalam bentuk visual, tahap ini berurusan pada desain sensorik dan presentasi pengaturan logis yang membentuk kerangka produk. Misalnya, melalui perhatian pada desain informasi, kita menentukan bagaimana harus mengelompokkan dan mengatur elemen-elemen informasi pada halaman web; melalui perhatian pada desain visual, kita dapat menentukan bagaimana konten tersebut harus disajikan secara visual. Menurut Garett $(2011,135)$ dalam mendesain secara visual situs web perlu memperhatikan beberapa aspek sebagai pertimbangan, yaitu:

- Melalui indra perasa, dalam akhir proses desain adalah bagaimana cara memberikan pengalaman kepada pengguna, menentukan bagaimana segala sesuatu tentang desain akan bermanifestasi ke panca indera pengguna. Yang mana dari kelima panca indera (penglihatan, pendengaran, sentuhan, penciuman, dan rasa) yang dapat kita gunakan tergantung pada jenis produk yang kita rancang.

- Penglihatan, dapat mengkomunikasikan tentang identitas merek salah satu alat utama yang digunakan untuk berkomunikasi menggunakan desain visual.

- Mengikuti arah mata, mengidentifikasi arah mata pengguna dalam 
menggunakan situs web agar konten yang tersedia dapat dijangkau oleh mata pengguna dengan mudah.

- Kontras dan keseragaman, kontras sangat penting untuk menarik perhatian pengguna terhadap aspek-aspek penting dari antarmuka, kontras membantu pengguna memahami hubungan antara elemen navigasi pada halaman, dan kontras adalah sarana utama berkomunikasi secara konseptual dalam desain informasi. Sedangkan mempertahankan keseragaman dalam desain adalah memastikan bahwa desain berkomunikasi secara efektif tanpa melebur atau membuat kewalahan pengguna.

- Tata letak (layout), untuk memposisikan letak konten atau fitur pada tempat yang tepat dan mudah dijangkau oleh pengguna.

- Palet warna dan tipografi, pemilihan warna dan gaya tulisan yang tepat meliputi kombinasi warna yang digunakan dan ukuran font pada tulisan yang disesuaikan.

Tahap bidang permukaan merupakan tahap akhir dari rangkaian elemen UX yang dimana pada tahap ini lebih menekankan pada tahap mempercantik atau polesan akhir pada tampilan situs web secara visual.

\section{METODE}

Metode yang digunakan pada kajian ini adalah metode kualitatif, yaitu penelitian yang menghasilkan data deskriptif berupa ucapan, tulisan, dan perilaku orang-orang yang diamati. Penelitian kualitatif ditujukan untuk mendeskripsikan dan menganalisis fenomena, peristiwa, aktivitas sosial, sikap, kepercayaan, persepsi, dan pemikiran manusia secara individu maupun kelompok (Ghony and Almanshur 2012). Kajian ini menekankan pada analisis dari proses berpikir secara induktif yang berkaitan dengan dinamika hubungan antarfenomena yang diamati, dan senantiasa menggunakan logika ilmiah (Gunawan 2014). Teknik pengumpulan data pada kajian ini adalah studi kepustakaan menggunakan data-data sekunder yang diperoleh dari berbagai buku dan artikel-artikel ilmiah berupa berita, jurnal, serta 
laporan penelitian yang terkait untuk diolah dan dianalisis lebih lanjut dengan masalah yang dikaji. Jenis riset ini diambil dengan dasar data-data di lapangan (field research) yang sudah di muat dalam buku-buku ataupun terbitan-terbitan terdahulu yang dikumpulkan oleh peneliti-peneliti lain (Simanjuntak and Sosrodihardjo 2014).

\section{HASIL DAN PEMBAHASAN}

\section{User Experience pada Web Perpustakaan}

Perkembangan dunia perpustakaan semakin melaju seiring dengan perkembangan teknologi informasi menuntut perpustakaan harus bertransformasi dari perpustakaan tradisional menjadi perpustakaan modern. Dalam perpustakaan tradisional, permasalahan yang dihadapi adalah bagaimana menyediakan dana untuk mendapatkan koleksi bermutu sehingga dapat mencukupi kebutuhan pemustaka dan agar setiap saat dapat dilakukan penyiangan serta pembaharuan koleksi. Pada perpustakaan online, permasalahan yang dihadapi adalah penyediaan biaya lebih besar digunakan untuk pengadaan jaringan internet ICT (Information Communication Technology), bandwidth yang bagus, jumlah komputer yang mencukupi, dan cepat dalam akses database serta sumber daya manusia yang mampu memelihara kecanggihan peralatan tersebut (Hartinah 2014). Saat ini cukup banyak perpustakaan yang tidak hanya memiliki bentuk fisik (gedung), melainkan juga telah memiliki bentuk virtualnya berupa situs web yang memuat berbagai sumber informasi tentang perpustkaan dan bahan perpustakaan yang dimiliki oleh sebuah perpustakaan. Bahkan melalui situs web tersebut, pemustaka dapat memperoleh bahan perpustakaan dalam bentuk elektronik seperti buku elektronik (e-book), jurnal elektronik (e-journal), dan berbagai sumber elektronik lainnya.

Layanan perpustakaan adalah komponen penting dari konten situs web perpustakaan. Menurut Clyde, beberapa situs perpustakaan memiliki tujuan yang bervariasi berfokus pada penyediaan informasi tentang perpustakaan dan layanannya sementara yang lain lebih berfungsi seperti 
portal, menyediakan tautan ke sumber daya Internet. Mereka mengatur konten ke dalam kategori: informasi perpustakaan, referensi, penelitian, instruksi, dan fungsi (Rennick 2019, 15). Karena layanan merupakan komponen penting, maka layanan yang disediakan pada konten situs web perpustakaan haruslah berorientasi pada kemudahan pemustaka dalam mengakses layanan-layanan tersebut. User experience atau pengalaman pengguna sangat penting dijadikan dalam dasar pembangunan sebuah situs web perpustakaan, karena pemustaka lah yang akan memanfaatkan situs web tersebut. Semakin bagus pengalaman pemustaka yang mengunjungi situs web perpustakaan, maka semakin sering pemustaka mengunjungi situs web perpustakaan tersebut.

\section{Implementasi Elemen User Experience pada Web Perpustakaan}

Tahap strategi pada elemen UX oleh Garett dapat diterapkan pada lembaga atau institusi non profit seperti perpustakaan. Pada dasarnya strategi perpustakaan sebagai pondasi utama yaitu perpustakaan perlu melihat kembali pemetaan atau rencana strategi dari berbagai sisi. Dari sisi membangun kualitas layanan berupa kebijakan, koleksi perpustakaan, layanan, sumber daya manusia (SDM), anggaran, dan infrastruktur. Salah satu cara untuk meningkatkan layanan perpustakaan antara lain dengan menyediakan sarana situs web perpustakaan.

Perpustakaan merupakan sistem informasi yang memungkinkan kegiatan berdasarkan proses kerja yang mencakup beberapa kegiatan teknis perpustakaan diantaranya: pertama, pengadaan koleksi dan bahan perpustakaan (akuisisi). Kedua, inventarisasi berupa pencatatan koleksi, pemeriksaan, pengelompokkan, dan stampel pada bahan perpustakaan. Ketiga, pengkatalogan bahan perpustakaan. Keempat, sirkulasi, on serve dan interlibrary loan merupakan bagian dari perpustakaan yang langsung berhubungan dengan pemustaka (Hartono 2017, 31).

Pada tahap bidang lingkup mengenai apa yang menjadi batasan dalam penciptaan pengalaman bagi pengguna dalam mengakses situs web. menurut Garett lingkup UX terbagi menjadi dua sisi yaitu: sisi software 
interface (konten) dan hypertext system (konteks). Di sisi konteks, sistematika fungsional harus dipertimbangkan artinya bahwa konten-konten yang ada di halaman situs web perpustakaan harus memiliki fungsi agar tidak ada konten yang tidak terpakai oleh pemustaka. Contohnya, adanya konten tanya pustakawan yang dapat difungsikan bagi pemustaka jika ada yang ingin ditanyakan kepada pustakawan terkait sumber informasi. Sedangkan di sisi konten, kebutuhan-kebutuhan informasi harus pula dipertimbangkan secara matang, artinya dalam mendesain konten-konten untuk web perpustakaan harus di evaluasi apakah konten tersebut layak di tampilkan dan dibutuhkan oleh pemustaka ataukah tidak.

Kemudian pada tahap di bidang struktur terbagi menjadi dua struktur yang harus dibentuk, yaitu desain interaksi dan arsitektur informasi. Desain interaksi dapat menggambarkan struktur informasi secara konseptual tentang bagaimana alur kerja pemustaka dapat berupa flowchart dalam mengakses situs web perpustakaan sehingga tingkat kesalahan dapat diperkecil. Misalnya, alur kerja log in seorang pemustaka agar dapat mengakses situs web perpustakaan, proses temu kembali informasi di web perpustakaan, dan penelusuran katalog online di web perpustakaan. 


\section{USER LOGIN SYSTEM for XYZ App}

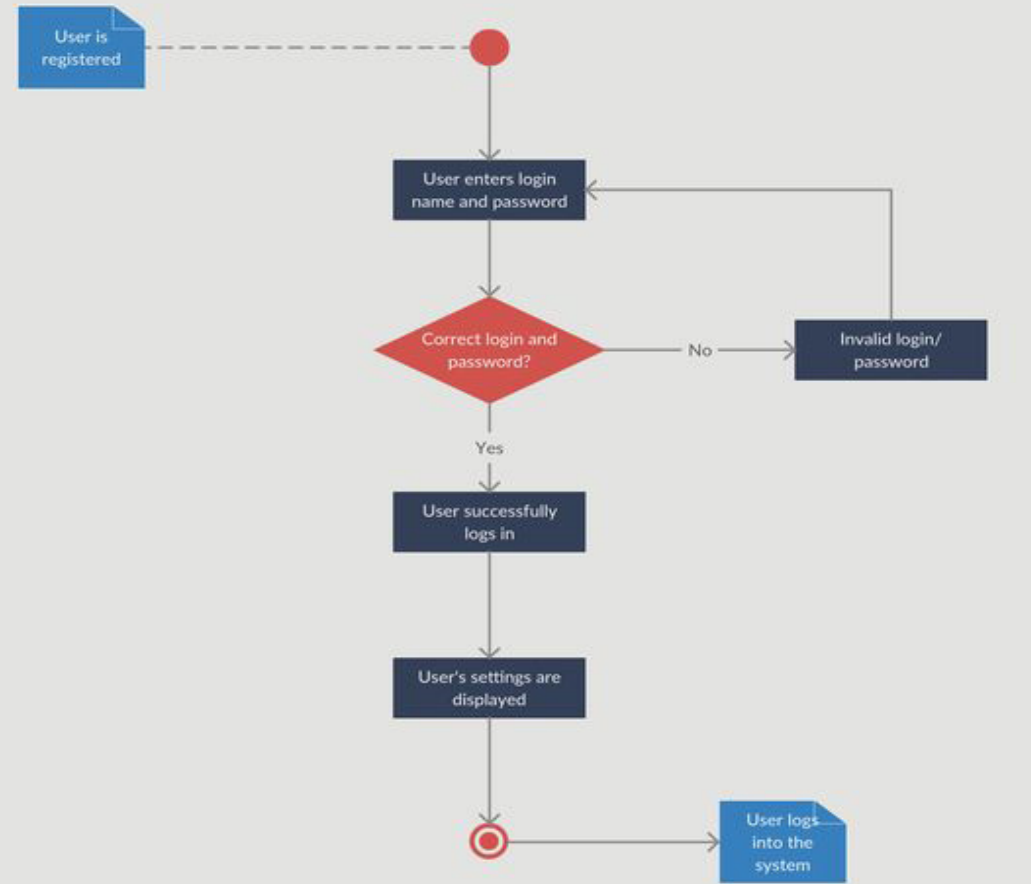

creately

Gambar 2. Alur kerja log in pemustaka

Sumber: https://id.pinterest.com/pin/464011567853969405/ (2020)

Kemudian struktur arsitektur informasi yang berkaitan dengan pemustaka memproses informasi secara kognitif sehingga informasi yang disajikan dapat dipahami oleh pemustaka. Arsitektur informasi dapat berupa susunan konten, fitur, bahasa, dan metadata yang dimuat dalam situs web perpustakaan. Misalnya, dalam konten pencarian terdapat keterkatian dengan konten yang memuat sumber database buku, artikel, jurnal, pangkalan data penelitian, film, dll. Contoh arsitektur informasi di web perpustakaan seperti pada gambar 3 . 


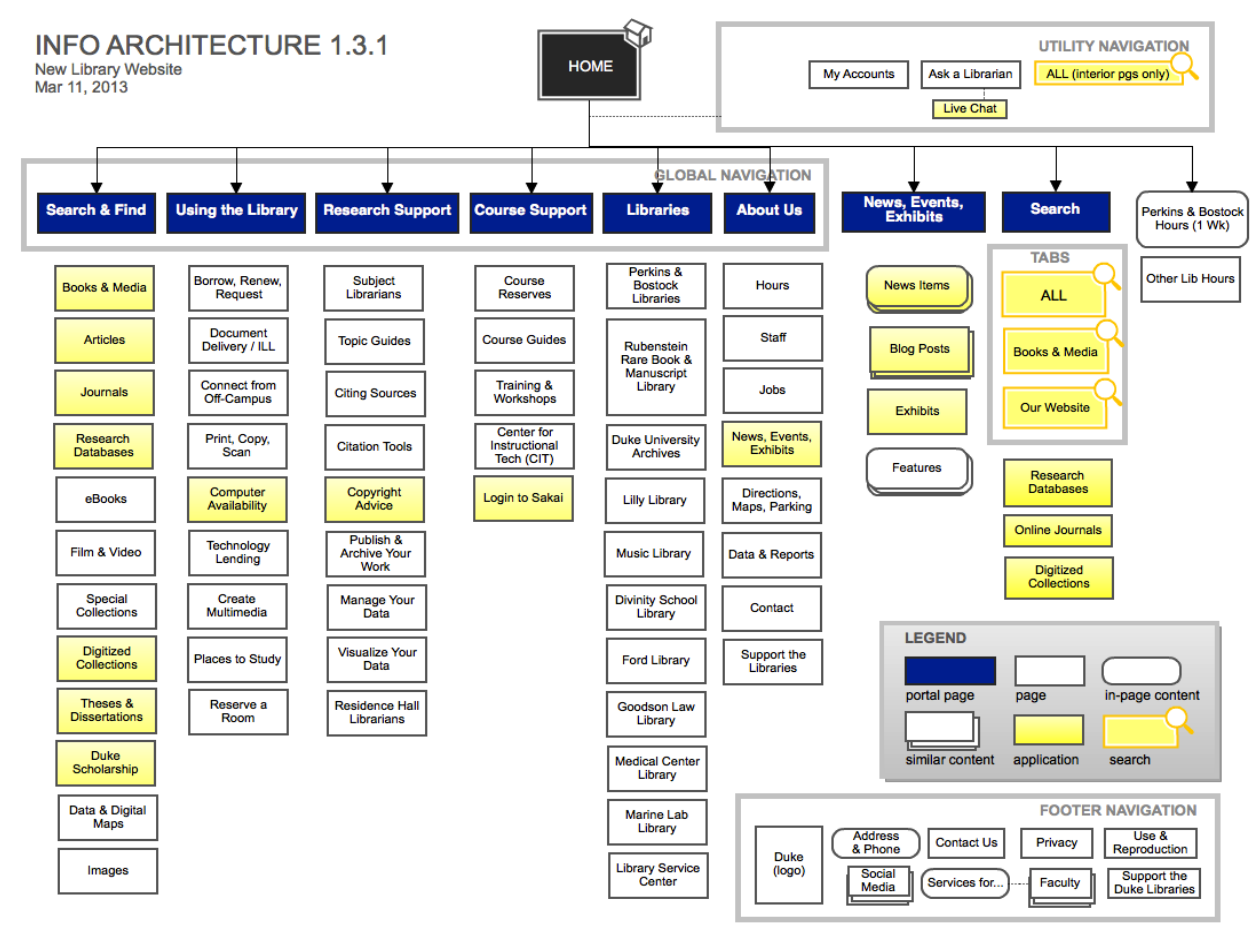

\section{Gambar3. Arsitektur Informasi di Situs Web Perpustakaan}

Sumber: https://id.pinterest.com/pin/668151294692312757/ (2020)

Elemen ke empat adalah bidang rangka terdapat tiga aspek yaitu Interface design, navigation design, dan information design. Pada tahap UX ini merupakan proses awal bagaimana konten-konten akan di tampilakan ke halaman situs web atau biasa disebut dengan wireframe. Tahap ini merupakan pengaplikasian dari tahap sebelumnya yaitu arsitektur informasi. Bidang rangka ini berupa layout-layout atau tata letak konten yang akan di sajikan pada web perpustakaan. 


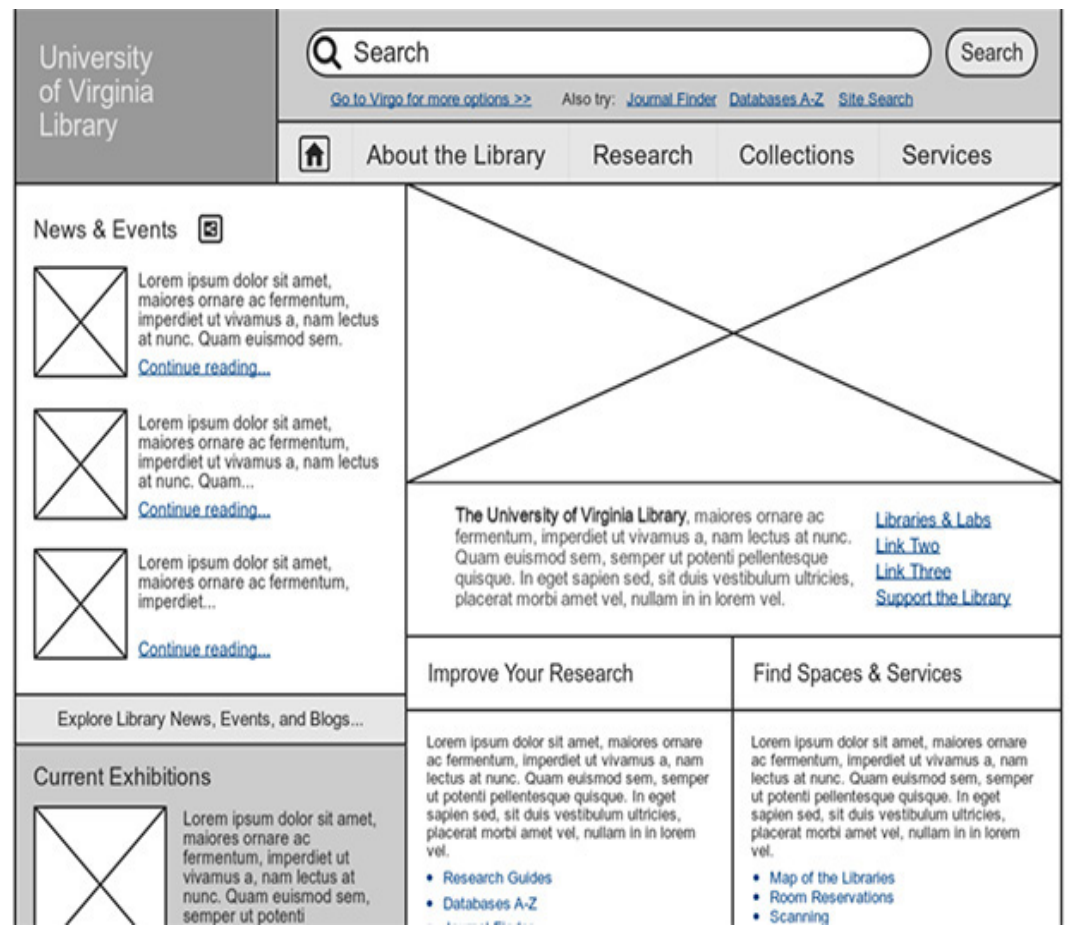

Gambar 4. Desain Wireframe Web Perpustakaan

Sumber: https://onextrapixel.com/the-design-pattern-wireframe-libraries-guide/ (2020)

Terakhir adalah elemen bidang permukaan pada tampilan situs web perpustakaan. Desain Wireframe yang telah dirancang diaplikasikan dalam bentuk visual halaman situs web perpustakaan dengan menambahkan efek kontras, kombinasi warna, gamabar, dan tipografi agar membuat web perpustakaan semakin menarik mata pemustaka. Pada tahap ini merupakan tahap, memperindah halaman web perpustakaan. Berikut ini salah satu contoh tampilan situs web perpustakaan, yaitu: perpustakaan Alexandria. 


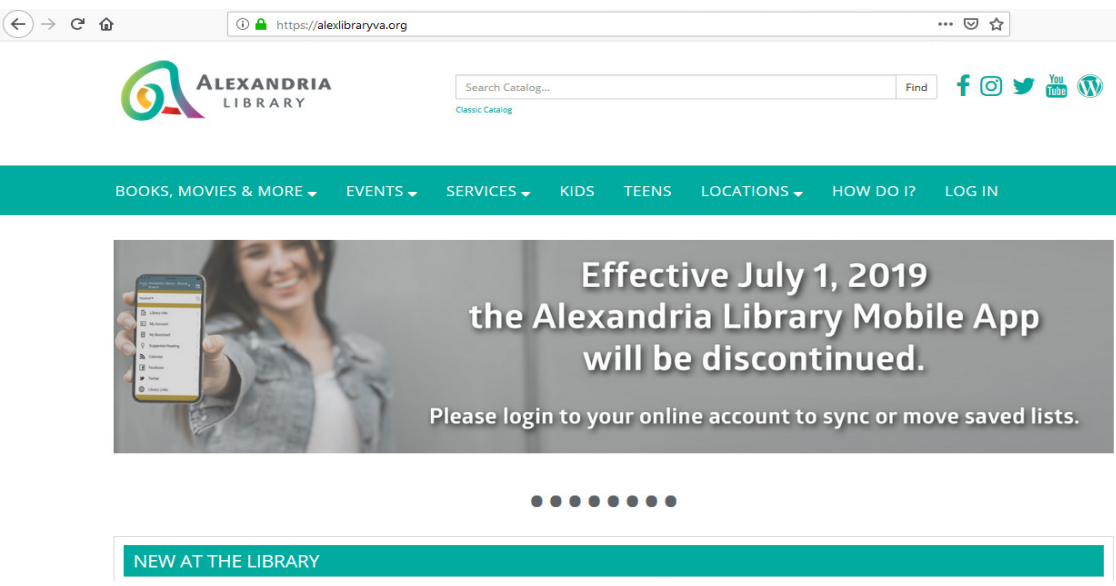

\section{Gambar 5. Tampilan Website Perpustakaan Alexandria Sumber: https://alexlibraryva.org/ (2020)}

- Memiliki dua kotak layanan pencarian, yang masing masing memiliki fungsi yang berbeda, yaitu:

Kotak pencarian pertama berfungsi untuk penelusuran katalog koleksi perpustakaan Alexandria.

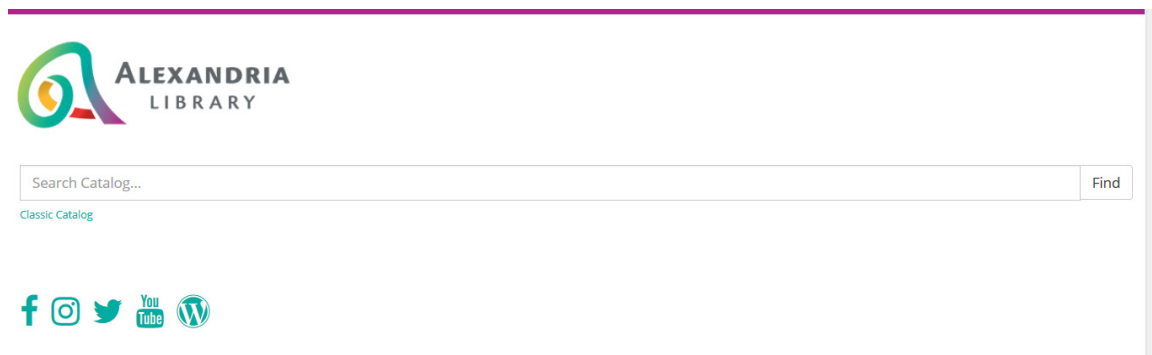

\section{Gambar 6. Tampilan Layanan Pencarian Website Perpustakaan Alexandria \\ Sumber: https://alexlibraryva.org/ (2020)}

Selanjutnya, kotak pecarian kedua berfungsi sebagai penelususran informasi yang akan mengahsilkan informasi rujukan alamat web lengkap yang dibuat oleh perpustakaan Alexandria. 


\section{Gambar 7. Kotak Pencarian Website Perpustakaan Alexandria}

Sumber: https://alexlibraryva.org/ (2020)

- Pada situs web perpustakaan Alexandria, disediakan berbagai konten seperti koleksi bahan perpustakaan, even (acara), layanan, area anakanak, area remaja, dan papan $\log i n$. Penempatan konten yang disajikan juga mudah dijangkau oleh mata pemustaka, sehingga pemustaka tidak perlu melakukan scroll yang berulang-ulang pada halaman web untuk mencari konten-konten yang tersedia.

\section{Gambar 8. Konten-Konten Website Perpustakaan Alexandria}

Sumber: https://alexlibraryva.org/ (2020)

Dan keterkaitan konten-konten utama yang disediakan menghubungkan pada sub-sub konten lainnya, seperti pada konten Books, Movies \& More yang menghubungkan pada konten yang memuat semua koleksi-koleksi perpustakaan.

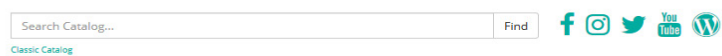

\section{BOOKS, MOVIES \& MORE - EVENTS - SERVICES - KIDS TEENS LOCATIONS - HOW DO I? LOG IN}

NEW ITEMS

DIGITAL COLLECTION

RECOMMENDED

GUIDES

Fiction

eBooks

Best Sellers

Book Match

Find A Good Book

Career \& Jobs

Computers \& Tech

Digital Literacy

DIY \& Hobbies

Sraphic Nov

Financial Literacy

Early Literacy

Genealogy

Government

Health \& Medicine

History

Audiobooks
Young Adult

Music

All Digital Collection

Language \& Culture

Science

All Guides

Gambar 9. Konten-Konten Website Perpustakaan Alexandria

Sumber: https://alexlibraryva.org/ (2020) 
- Kontras dan keseragaman warna pada situs web perpustakaan Alexandria di dominasi dengan warna putih sebagai backgroud, kolaborasi warna yang digunakan adalah hijau, toska, kuning, ungu, dan merah sesuai pada logo perpustakaan alexandria.

- Dari segi tipografi, gaya tulisan dan ukuran font tulisan yang digunakan mudah di baca oleh pemustaka dengan beberapa konten utama yang menngunakan font huruf yang lebih besar dan tebal.

- Pada web perpustakaan Alexandria, menyajikan tampilan web utama yang sederhana dengan jarak navigasi satu kali scroll yang artinya web tidak menampilkan informasi-informasi ganda yang semakin memperbanyak tampilan web. Mata pemustaka tidak akan dipusingkan dengan banyak nya tulisan dan konten-konten ganda.

- Pada bagian akhir tampilan web, terdapat konten layanan informasi terkait institusi perpustakaan.

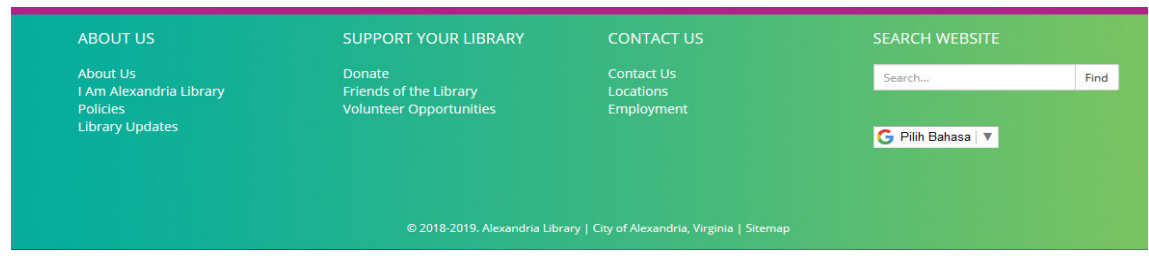

Gambar 10. Konten Layanan Informasi Website Perpustakaan Alexandria

Sumber: https://alexlibraryva.org/ (2020)

\section{KESIMPULAN}

Perpustakaan menawarkan begitu banyak layanan yang beragam, dengan adanya situs web dapat menjadi media mempromosikan perpustakaan secara efektif. Selain itu, dengan adanya web perpustakaan semakin memperluas jangkauan akses terhadap pemustaka. Web perpustakaan disajikan untuk mempermudah dalam memenuhi kebutuhan informasi pemustaka, maka sudah selayaknya bahwa pembangunan sebuah web 
perpustakaan harus didasarkan pada kebutuhan pemustakanya. Membangun sebuah situs web harus dirancang berdasarkan pengalaman pemustaka, sebagai pengguna yang menggunakan layanan web tersebut. Dasar-dasar user experience sangat dibutuhkan dalam merancang sebuah situs web perpustakaan. Semakin baik pengalaman pemustaka dalam menggunakan situs web perpustakaan, maka akan semakin baik pula kualitas layanan web suatu perpustakaan.

\section{DAFTAR PUSTAKA}

Abbas, Asad, and Ali Faiz. 2013. "Usefulness of Digital and Traditional Libraries in Higher Education.” Int. J. Services Technology and Management 19.

Deacon, Pamala B. 2020. UX and UI Strategy: A Step by Step Guide on UX and UI Design. United States of America: $\triangle$ Independently published.

Fahmi, Khairul, Agus Tri Haryono, Indah Fitri Astuti, and Dedy Cahyadi. 2016. "Perancangan Dan Implementasi Aplikasi Perpustakaan Berbasis Multitenant." Informatika Mulawarman : Jurnal Ilmiah Ilmu Komputer 11 (1). https://doi.org/10.30872/jim.v11i1.196.

Garett, Jesse James. 2011. The Elements of User Experience: User-Centered Design for the Web and Beyond Second Edition. Second. United States of America: New Riders.

Ghony, M. Djunaidi, and Fauzan Almanshur. 2012. Metode Penelitian Kualitatif. Yogyakarta: Ar-Ruzz Media.

Gunawan, Imam. 2014. Metode Penelitian Kualitatif: Teori Dan Praktik. Jakarta: Bumi Aksara.

Hartinah, Sri. 2014. Metode Penelitian Perpustakaan. Tangerang Selatan: Universitas Terbuka.

Hartono. 2017. Manjemen Sistem Informasi Perpustakaan: Konsep, Teori, Dan Implementasi. Yogyakarta: Gava Media.

Interaction, Ergonomics of human-system. 2010. ISO 9241-210 First Edition. https://www.sis.se/api/document/preview/912053/. 
Munthe, Rio Donaroe, Komang Candra Brata, and Lutfi Fanani. 2018. "Analisis User Experience Aplikasi Mobile Facebook (Studi Kasus Pada Mahasiswa Universitas Brawijaya)." Jurnal Pengembangan Teknologi Informasi Dan Ilmu Komputer 2 (7).

Rennick, Brian. 2019. "Library Services Navigation: Improving the Online User Experience." Information Technology and Libraries 38 (1). https:// doi.org/10.6017/ital.v38i1.10844.

Simanjuntak, Bungaran Antonius, and Soedjito Sosrodihardjo. 2014. Metode Penelitian Sosial: Edisi Revisi. Edisi Revi. Jakarta: Yayasan Pustaka Obor Indonesia. 
Laylatul Munawaroh 